\title{
YALE
}

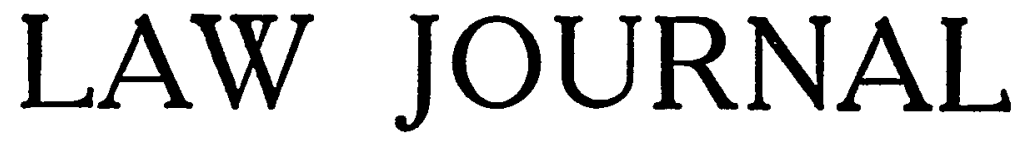

\begin{tabular}{lll}
\hline \hline Vol. XXIX & FEBRUARY, 1920 & No. 4 \\
\hline \hline
\end{tabular}

\section{SEPARATION OF GOVERNMENTAL POWERS}

\author{
FREDERICK GREEN \\ Professor of Law, University of Illinois
}

Many recent writers have remarked a growing tendency, if not a compelling need, to vest in administrators a large discretion, and an authority to make rules which amounts, in a sense, to a delegation of real, though limited, legislative power. Some writers deny the desirability of the separation of powers, as they conceive it, and dispute the value and even the reality of the theoretical division of governmental functions upon which it rests. ${ }^{1}$ Some think that the distinction of functions is largely a matter of convention and convenience, and that the same kind of power may be exercised by a legislature and called legislative, by an administrator and called executive, or by a court and called judicial. Professor F. J. Goodnow, for instance, quotes from a French author the statement that "the mind can conceive of but two powers: that which makes the law and that which

I". . the one obvious method by which the past sought refuge from the dangers of authority has proved in fact delusive. . . . It is in fact a paper merit for the simple reason that in practice it is largely unworkable. - . . The business of government does not admit any exact division into categories." Laski, Authority in the Modern State (1919) 70, 71. "Modern political science has, however, generally discarded this theory, both because it is incapable of accurate statement, and because it seems impossible to apply it with beneficial results in the formation of any concrete political organization." Goodnow, Comparative Administrative Law (1903) 20. See also Baldwin, The American Judiciary (1905) 23, 24; Bondy, The Separation of Governmental Powers (1893) 76-80; Goodnow, Politics and Administration (1900) 9, 10, 22; Powell (1912) 27 PoL. StIENCE Q. 215; Woodrow Wilson, Congressional Government (1885) 273, 284, 290; I Duguit, Manuel de droit constitutionnel (I9II) pars. 63,64 ; Hobbes, Leviathan (165I) ch. I8. 
executes it. There is no place, therefore, for a third power by the side of the first two."' Mr. Goodnow, somewhat similarly, argues that acts of a state, like those of an individual, can naturally be grouped under two heads only, those necessary to the expression, and those necessary to the execution, of the will. The former he calls political, the latter administrative, action. He says the theory of three separated powers incorporated in our constitutions has proven "to be unworkable as a legal principle" because there is "a common borderland" between them, and that it is really "existent in our constitutional law only in an attenuated form," and that it has become "an unworkable and unapplicable rule of law."

There is no occasion to deny the possibility of a twofold division of governmental functions, nor its usefulness for some purposes. But there is need to challenge an assertion that the tripartite division is a fiction either of law or of political science, void of significance or value, necessarily disregarded in fact, or incapable of consistent application except by pretence. Perhaps there are differences which are inherently differences of kind. It may be that the differences between mind and matter, and between is and ought are such. But most classifications of human affairs rest upon differences of degree, like the difference between a grain of sand and the rock of Gibraltar. We can imagine a grain of sand increasing by degrees until it gets as big as Gibraltar, but when a change has progressed so far that we need to alter our manner of dealing with the changing thing we view it as a change in kind. What we generally mean by a different kind of thing is a thing that we need to treat differently.

Mr. Goodnow's classification rests on differences of degree to the same extent as the threefold classification. He says his classification applies to the single person as well as to the state, and therefore we might expect him to say that it is the distinction between deciding what to do, and doing it. But he says it is a distinction between the expression of the will, and putting the will into effect. Since important decisions may be made without any expression of will other than that involved in the act of putting the decisions into effect, it is not entirely clear whether Mr. Goodnow brings under the head of expression of the state's will merely the enunciation of rules, or whether he intends to embrace all decisions on matters of policy, even such as may be involved in an executive dealing with a particular case. Whichever he means, such an "expression of will" forms an element of almost every governmental action. When a legislature passes a law for maintaining traffic policemen; when the chief of police details particular policemen to control traffic at particular street intersections; when the policeman whirls about the sign that says "Go," and makes it read "Stop," each has to decide what policy requires, and each expresses

\footnotetext{
${ }^{2}$ Goodnow, Politics and Administration (1900) 9, I0, I2.
} 
the will of the state. Indeed, as numbers of persons are dealt with by word of command, each in some sense legislates. Yet Mr. Goodnow does not hesitate to treat such acts as those of the chief of police or patrolmen as involving only the sort of thing he means by administration. It is no real objection to a classification of governmental activities that action classed under one head savors in some degree of the characteristics of action classed under another. The distinction between earth, air and water is not rendered "unworkable" by the existence of dust, mud and clouds, or "unapplicable" by the fact that a traveler may sometimes choose between railroad, airplane and steamship. It is true that judges' decisions in a certain sense make law, that legislatures sometimes pass acts for particular cases, that the same result may sometimes be accomplished by invoking the action either of legislature, executive or court, and, as has been said already, that administrative officers may be vested with real, though limited, legislative power. These things indicate that the separation of powers works elastically, but they neither prove nor disprove the desirability or feasibility of putting limits on the kind of power a given functionary may exercise. Though it is not always physically necessary to formulate the state's will separately from enforcing it, there may be good reason for imposing a legal necessity for usually doing so, by separating the powers.

Furthermore, adjudication differs essentially from administration. To compare a state to a person, and to speak of the execution of its "will," is likely to mislead. The state is concerned with two matters of a different sort; first, what it does itself; second, what its people do to each other. Its regulations are largely not of public, but of private, affairs. They concern private "will." The state does not decide whether a man shall sell his land or give his money to charity. It confers rights in case he does these things, but it is for the persons concerned to insist upon their rights or to waive them. Only when private wills conflict does the state determine which will is entitled to prevail, and then the winner may enforce the decision or not, as he chooses. In adjudication, the will of the state is conditional on the will of the parties. It has no will of its own. That is why judging between parties is the chief function of primitive governments, and precedes law making and executive force, ${ }^{3}$ and why judicial tribunals in civilized countries are distinct bodies treated as discharging a distinct office. A lawsuit may be an enterprise of the parties, enriching or impoverishing them, but it is not an enterprise of the state, analogous to conducting a war, levying a tax or paving a street. In a suit over the price of land, the subject-matter of the state's action is not dollars or land, but the rights of others.

The case is the same if the suit involves the legality, not of private,

\footnotetext{
See Esmein, Separation des pouvoirs, 402-404.
} 
but of governmental, action. To challenge the authority of an officer is to assert that what he does is not the "will" of the state. It raises the question what the state's will is. To will and to enforce that will, and to determine what that will has been in order to discover and protect rights under it are matters of a different kind. This is equally true of prosecutions for crime. A government conceivably might arrest disturbers of the peace, throw them into jail and keep them there for punishment, all in a single course of administrative procedure. But a government worthy of the name guards its people from violence and wrong not only from others, but from itself, and not only by physical measures, but by a system of legal rights." But legal rights give no sure protection unless there is also an opportunity to invoke specific governmental action to determine whether they have been violated. Therefore a man against whom public force is brought generally has a right to a formal determination whether there is authority to bring it. The function is distinct from and even in a sense opposed to the function of repressing crime. It is the function of protecting the individual from wrong. The criminal and the administration are on opposing sides. The court judges between them. When we say we live under a government of laws, we recognize the protection of rights as a function of government set apart from and in some degree above the administrative power. It would shock us if the prisoner's guilt and its punishment were determined by his jailer, as in a case of breach of prison discipline. It would shock us if, whenever a court made a decision, the governor could reverse it. Yet if it is on a footing with other executive acts, there should be no impropriety in empowering him to do so..$^{5}$

It is true that by conditioning the authority of executives on their opinion as to facts instead of upon the existence of the facts, legislatures, as will be seen, may narrow the field of individual freedom and widen that of executive power; but this increases the importance of distinguishing the ordinary executive authority from the power to judge the limits of that authority. It is also true that such matters as the assessment of values incident to the collection of taxes and to the exercise of eminent domain may be carried through by the executive department, being classed as pertaining to the satisfaction by government of its own needs, much as breaches of prison discipline are classed as pertaining to prison administration. Yet since tise fourteenth century, the provision of Magna Carta that no free man should be taken, imprisoned or destroyed, nor proceeded against by royal power, except through the judgment of his peers or the law of the land has been regarded as securing the separation of trial for

- See Stimson, Federal and State Constitutions (Ig08) II; Dicey, The Law of the Constitution (8th ed. 1915) I83-184.

SSee Esmein, ibid., 402-404. 
crime from administration in general. So essential is this to fundamental justice that though due process of law does not in general require a separation of powers, ${ }^{\circ}$ it does prevent an administrative determination of guilt. ${ }^{7}$ Courts and legislative bodies may punish for contempt. Executives may not.

It is of fundamental importance to notice that the difference between legislative, executive and judicial action depends upon the kind of action taken and not upon the kind of mental process involved in deciding whether and how to take it. ${ }^{8}$ Misconception on this point has caused much confusion. If a claim is made against a principal on a contract alleged to have been concluded by his agent, the principal may try to ascertain the facts from witnesses and the law from law books, or he may go to a lawyer for an opinion or to an umpire for a decision, and as a result may pay the claim; but though principal, lawyer and umpire have gone through the same train of thought, as a judge would on a trial, they plainly have not exercised a judicial function because they have exercised no governmental power at all. If the contract claim were against a city, and the proper administrative officer of the city, after inquiry, thought it valid, and paid it, there would be governmental action involving the same mental processes as adjudication, but the action would be administrative, not judicial, because the purpose and consummation of the proceeding were administrative. But if a debtor refuses to pay and is sued, all exercises of governmental power by the court are judicial, because they are steps in the giving of judicial relief.

In what then does the distinction consist? To hazard definitions in an attempt to be explicit, it may be said:

Legislation is the creation by the state of a right (including an authority, a privilege or an immunity), duty, or status not dependent on the existence of a previous right, duty or status.

Adjudication is the imposition of a specific duty in personam, or of a liability, or the granting of a right or status which is dependent

- Dreyer v. Illinois (1902) I87 U. S. 71, 23 Sup. Ct. 28; Prentis v. Atlantic Coast Line Co. (1908) 211 U. S. 210, 225, 29 Sup. Ct. 67.

${ }^{7}$ Cleveland, etc., R. R. v. People (1904) 212 Ill. 638, 72 N. E. 725; Interstate Commerce Commission v. Brimson (1894) 154 U. S. 447,485 , I4 Sup. Ct. II25. "It is not consistent with the theory of our government that the legislature should, after having defined an offense as an infamous crime, find the fact of guilt and adjudge the punishment by one of its own agents." Wong Wing $v$. United States (1896) I63 U. S. 228, 237, I6 Sup. Ct. 977.

s'It is 'the nature of the final act' that determines 'the nature of the previous inquiry." Hughes, J., in Louisville, etc., $R . R . v$. Garrett (IgI3) $23 \mathrm{I}$ U. S. 298, 307, 34 Sup. Ct. 48; and see People v. Apfelbaum (I9II) 25I III. 18, 95 N. E. 995 ; Klafter v. Board, etc. (I913) 259 I11. 15, I02 N. E. I93.

'See Donahue v. Will Co. (188I) I00 Ill. 94; George v. People (1897) 167 Ill. 447,47 N. E. 74I; People v. Kipley (1897) I7I Ill. 44, 65, 49 N. E. 229; Devine v. Brunswick-Balke Co. (1915) 270 Ill. 504, I10 N. E. 780 . 
on a previous right or duty, in that it is imposed by way of giving effect to a right or duty determined to exist or to have existed, or by way of redress or punishment for its violation.

Administration probably cannot be so closely defined. It consists in a management of public affairs and includes all state action not part of a process of legislation or adjudication which affects rights or involves the use of adverse force. It cannot be closely defined, because, as will be explained, it may slightly overlap the legislative field, in that administrative officers may be vested with a limited, subsidiary discretion in the creation of rights and duties, and also because it may slightly overlap the judicial field, in that administrative officers may be vested with power to put existing rights into effect where doing so does not affect other rights adversely. With that part of administration which, as in many of the scientific activities of government, involves no control over rights, but only such action as might be carried on by private persons, we are not concerned.

IEGISLATIVE POWER

Legislation may be permanent or temporary, general or special. A permanent revenue law or a tax for a particular work of public benefit, a general divorce, pension or incorporation law, or an act granting divorce, pension or incorporation to particular persons are alike legislation..$^{10}$ Divorces, pensions and incorporation were once usually granted by special act; and this required the legislature to make up its mind in each case whether sufficient reason existed. It was seen to be more simple and just to determine generally what facts are good reason for divorce, pension or incorporation and to pass an act conferring a right to an award thereof to any person in whose case the facts exist. It is then competent to vest a court with power to determine on application whether the conditions of the right are fulfilled, and, if so, to effectuate it by decree. The process which might have been purely legislative has been divided into two parts, one of which is judicial. But the legislature may frame its action so that the grant of incorporation, pension, or, it would seem, divorce, if by consent, shall come from the executive and not from a court. It can make it the duty of an administrative officer when the conditions are fulfilled (in fact or in his opinion, whichever the statute provides), and application duly made, to grant a certificate of incorporation or award a pension. This duty is purely executive. It administers the law. That in order to administer it correctly it is necessary to determine what the law and facts are is immaterial. Such a determination is generally necessary as a preliminary to administrative action; for instance, in arresting a disturber of the peace.

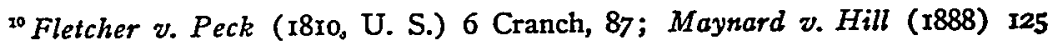
U. S. 190, 8 Sup. Ct. 723. 
But the legislature could not confer on an executive officer power to grant a decree of divorce for a specified cause without the consent of the parties, so long as marriage remains a matter involving individual rights. To deprive a person of a right in respect to another, putting an end to it upon the ground that he is not entitled under the law to possess it any longer, is to adjudicate. ${ }^{11}$ In short, much as a bombardment may be carried on from land, air or water, so a corporation may be created by action which -is legislative, administrative or judicial. Actions differing in nature are invoked to work the same result.

This is as it should be. Each of the three departments exists to help, according to its own function, in the general work of government. It may properly be used to carry out any measures for which it is adapted, and it is for the law-making power to decide to what extent to use it. ${ }^{12}$ It is a mistake to think that the distinction between the functions of government is unreal because there is often a choice which to use. As to mental processes involved the powers are indifferent; but as to results to be accomplished, and in a lesser degree as to the mode of acting, they are circles which partly overlap. The doctrine is not that no two of them may include any common ground, but that none of them may pass without its own boundaries and intrude upon territory belonging solely to another. The executive cannot take action which is legislative or judicial in such sense as to be non-executive, and so of the others. But it is no constitutional objection to executive action that it requires determination of law or fact or, in some degree, policy, or that instead a court or legislature might have acted in its own way and produced a like result; although it may be a good political objection that a court or legislature could have done it better. ${ }^{13}$

Since the separation of powers operates by way of exclusion, the important thing is to consider what this exclusion is, - what power is non-legislative, non-executive and non-judicial. The legislature as the creator and destroyer of rights is in a sense the superior department, since, as Locks puts it, "the legislature is no otherwise legislative of the society, but by the right it has to make laws for all the parts."14 By fixing the rights of persons, the duties of executives and the jurisdiction of courts, it largely determines the form the government shall

\footnotetext{
"A court clerk cannot enter judgment by default, but it seems that he may enter judgment on confession. Hall $v$. Marks (1864) 34 Ill. 358.

${ }^{2}$ United States $v$. Woo Jan (1918) 245 U. S. 552, 556, 38 Sup. Ct. 207. It seems that the legislature may confer power to determine election results either on an administrative body or on a court. Lyons $v$. Becker (IgI6) 272 IIl. 333,336 , III N. E. 980 .

${ }^{23}$ Thus the legislature may appropriate money to pay a claim against the state, although the court of claims has decided that the claim is unfounded. Fergus v. Russel (1917) 277 I11. 20, II5 N. E. 166.

"Locke, Treatise on Government (I690) Bk. 2, ch. I3, par. I50.
} 
take, the extent to which the power of the administrative and judicial departments shall be called into play.

Fixing a railroad rate confers on all who tender goods for shipment a right against the carrier to have that rate. It governs an undetermined multitude of persons and future transactions. When given by a legislature, it is given as a new, independent right, and not as an enforcement of a preexisting one. Therefore it is legislation. ${ }^{15}$ But though a legislature may itself fix rates it may instead provide that they shall be such as a board determines to be reasonable. The board only determines a fact and promulgates the law accordingly. The legislature has adopted the determination in advance and provided for writing it into the law when made. ${ }^{16}$

A grant of a special right to a particular person is also legislation. ${ }^{17}$ But where it is obvious that the legislature is not attempting to create a new right, because it is desirable that a new right should exist, but to enforce, in favor of $\mathrm{A}$ against $\mathrm{B}$, what it believes to be an old right because it thinks the right exists and deserves enforcement, it is obvious that the legislature is attempting to adjudicate, and its act is invalid. ${ }^{28}$

${ }^{15}$ Prentis v. Atlantic Coast Line Co., supra; Louisville, etc., R. R. v. Garrett, supra.

${ }_{10}$ "Such a commission is merely an administrative body created by the state for carrying into effect the will of the state, as expressed by its legislature." Public Utilities Commission v. Chicago, etc., R. R. (Ig16) 275 Ill. 555, II4 N. E. 325. Louisville, etc., R. R. v. Garreti, supra; Minneapolis, etc., R. R. v. Railroad Commission (1908) I36 Wis. 146, I16 N. W. 905; Chicago, etc., R. R. v. Dey (1888, C. C. S. D. Ia.) 35 Fed. 866, 874; People v. Harper (1878) 91 Ill. 357 (commission may have power to fix charges for grain at an amount sufficient to cover expenses).

${ }^{27}$ See cases cited under note 10, supra.

13 Thus an act is valid which confers on a particular bastard a right to inherit from parents living when the act is passed. See Norman v. Heist (I843, Pa.) 5 Watts \& S. I7I. But an act is void which sets off specified land to a widow to be held as her dower. Edwards v. Pope (1842) 4 Ill. 465. It is within legislative power to give a particular plaintiff a right to special relief provided he obtains judgment. Edwards v. Pope, supra. Or to authorize a particular guardian to sell his ward's land for the ward's benefit. Mason v. Wait (1842) 5 IIl. 127. Or a particular administrator to sell land to pay judgment creditors. See Rozier v. Fagan (1868) 46 IIl. 404. But it is not within legislative power to authorize an administrator to sell land and pay from the proceeds alleged creditors who have not recovered judgment. Lane v. Dorman (184I) 4 Ill. 238 (to pay a specified claim); Rozier v. Fagan, supra (to pay debts generally). Or to make it the duty of a grantee, whose land is not under the control of the state, to reconvey to the grantor by a statute whose preamble recites that the conveyance was on a condition which has been broken. Board v. Bakewell (1887) I22 I1l. 339, 10 N. E. 378. Nor can a recital of a non-political fact in a statute be conclusive. And an act is invalid which sets aside a judgment and grants a new trial. Merrill v. Sherburne (1818) I N. H. 199. But acts validating defective acknowledgments (Steger $v$. Travelling Men's Ass. (1904) 
Though it is within legislative power to create a special private right, there is high authority for saying that to destroy a private right, unless under a general law or rule of policy, is not, in general, legislation. An act conveying to A, B's land, in which $A$ has no special concern, simply on the ground that $A$ can use it better or needs it more, is legislative in a sense, and certainly is not adjudication. But there was no thought of vesting in the government power to make particular confiscations for private benefit. That is not the kind of thing meant by legislation. ${ }^{10}$

As "the nature of the final act" determines the nature of the proceedings, the body that is to act is within its function in controlling matters incident to its action. Either house may, without usurping judicial power, admit to or exclude from participation in its affairs members whose qualifications are questioned $;^{20}$ summon witnesses and require them to answer questions relevant to contemplated legislative action; condemn to punishment for contempt persons who obstruct it or disobey its lawful commands; ${ }^{21}$ and apply force in preserving order at its sessions. ${ }^{22}$ But it is not within legislative power to conduct inquiries merely to satisfy curiosity or to enlighten the public, and neither the separate houses nor the whole legislature may compel attendance before a legislative committee for that purpose. ${ }^{23}$

A legislature may properly make the operation of its laws conditional when the condition affects their expediency. Thus a statute may be passed to be operative only in time of war. Where expediency

208 Ill. 236, 70 N. E. 236) or votes cast by disqualified electors (People v. Peltier (I916) 275 IIl. 2I7, Ir3 N. E. 856) justly confer new rights, and therefore are not judgments upon former rights. It is a doctrine of the civil law that where the canons of interpretation do not suffice, a later statute interpreting an earlier one binds the judges, even as to past cases. Coxe, Judicial Powers and Unconstitutional Legislation (1893) 60; Esmein, ibid., 437. Making law involves declaring what the law means, and reiterating the law's meaning to make it certain is thought naturally to appertain to the power of originally declaring it; and the maker knows his intention best. Eius est interpretari cuius est condere. But the common law with truer insight holds that legal duty depends on what the law ordains, not on what the legislature intended to ordain, or thinks it has ordained, and that interpretation, being the ascertainment of legal duty, is for the court. Rockhold $v$. Canton, etc., Society (1889) 129 III. 440,2 I N. E. 794.

${ }^{\prime \prime}$ See Newland v. Marsh (1857) r9 Ill. 376, 383; Loan Ass. v. Topeka (1874, U. S.) 20 Wall. 655.

${ }^{20}$ See Keating v. Stack (I886) II6 IIl. I9I, 5 N. E. 54I.

${ }^{2}$ People v. Keeler (1885) 99 N. Y. 463, 2 N. E. 615; In re Chapman (1897) I66 U. S. 661, 17 Sup. Ct. 677.

${ }^{22}$ Offenses "against the peace of our Lord, the King, his crown and dignity," the common law elected to treat as crimes. If so treated, due process forbids administrative determination of guilt. See note 12, supra.

${ }^{3}$ See Kilbourn v. Thompson (1880) 103 U. S. 168; In re Chapman, supra; People v. McDonald (1885) 99 N. Y. 463,2 N. E. 615. Cf. Ill. Rev. St. ch. III A, 72 . 
depends on the wishes of those whom the law will affect, its operation in a given locality may be made to depend on a majority vote in its favor.

\section{JUDICIAL POWER}

That a judgment, like a statute, creates a new right is clear because it is valid even though founded in misjudgment, as where no cause of action really existed. Within the jurisdiction, it extinguishes the original claim. It carries right to execution. It may include interest and costs. It differs from a statutory right in being conferred only on application, on specific persons, and after a determination that under existing law they have a right to it. This gives the measure of judicial power. Thus, as has been said, the legislature-may grant a right on conditions and empower a court, if it finds them fulfilled, to grant a new right by way of putting the old one into effect. So judicial power may be invoked to grant a certificate of incorporation, ${ }^{24}$ or of election, ${ }^{25}$ or to naturalize an alien. ${ }^{26}$ Taking acknowledgments and celebrating marriages, sometimes adduced as instances of administrative action by judges, seem to the writer to be judicial action of this kind, for the effect is to confer a new right on an applicant deemed entitled to receive it. But the condition must be one of fact, not of expediency. To grant a right because it is expedient to grant it is to make law. A statute which directs a court to grant a right upon proof that it ought to be granted is void as attempting to confer legislative power. A court cannot be empowered to incorporate a city upon finding that the city ought to be incorporated, ${ }^{27}$ or "that the interests of the inhabitants will be promoted" ; 28 but may have power to create a drainage district on petition and proof that the drains will be useful. ${ }^{29}$ It may determine what location has been granted a street-railway and enter an order fixing it; but it is not within judicial power, as has been held, to determine what location, motive power and track will be the proper ones, and issue license to use them. ${ }^{30}$ Power to issue licenses to fit persons has generally been upheld..$^{31}$ The principle is clear, but matters of fact and of expediency blend. Where the character of a thing

\footnotetext{
${ }^{24}$ Wahoo v. Dickinson (1888) 23 Neb. 426, 36 N. W. 813; Blake v. People (I884) rog Ill. 504.

${ }^{25}$ Moore v. Mayfield (1868) 47 Ill. 167; Dale v. Irwin (1875) 78 Ill. I70; Lyons v. Becker (I916) 272 Ill. 333, 336, III N. E. $980,982$.

${ }^{\Rightarrow} \mathrm{Cf}$. Supervisors of Election (1873) II4 Mass. 247. Courts may be empowered to grant licenses to sell liquor. Hall, Cases on Constitutional Law (rgr3) 84, note.

${ }^{2}$ Galesburg $v$. Hawkinson ( 1874$) 75$ Ill. 152.

${ }^{28}$ State v. Simons (1884) 32 Minn. 540.

${ }^{2}$ Blake v. People (1884) 109 Ill. 504. And see People v. Nelson (1890) I33 IIl. 565, 598, 27 N. E. 217,225 ; and cases cited in Hall, ibid., 86, note.

${ }^{30}$ Appeal of Norwalk Street Ry. (1897) 69 Conn. 576, 37 Atl. 1080.

${ }^{31}$ See Hall, ibid., 84, note.
} 
depends on circumstances, we cannot set up a quantitative standard for determining its character. And where a quantitative standard is impracticable we are often driven to using terms which savor of expediency. Speed must not be dangerous, regulations unreasonable, or goods unfit for use. There is conflict in the cases as to the degree in which room may be left for considerations of expediency to affect the determination. The separation of powers is not intended to prevent employing that organ of government whose characteristic mode of action is most appropriate for dealing with the situation. Where a standard of pure fact is impossible, and the conditions are so defined that when the facts in any case are ascertained there is little room for difference of opinion as to whether they come within the standard as defined, the power of the court should be upheld.

Judicial power acts specifically. To order a man to fulfill in general a legal duty to others, would duplicate the rule of law by adding a new obligation to obey the order, and would be to legislate. A court can go no farther in this regard than to enjoin, or to order specific performance, in favor of a party threatened with injury. It has been held that as a public utility company is bound to serve at a reasonable rate, a court may be empowered, on the application of a person to whom such service has been denied, to determine a reasonable rate and to direct the rendering of service at that rate to that person for a limited time..$^{32}$ But the court cannot be empowered on such an application to require the utility to adhere to the rate for all customers. $^{33}$ As already explained ${ }^{34}$ that would be to take part in legislation. The court would be the mouthpiece of the legislature reenacting the law in specific terms. The doctrine is that although it may be made an administrative function to ascertain and declare the existence of a fact upon which a statute is to take effect, as when demobilization is complete, or what rate is reasonable, it cannot be a judicial one.

$=$ In re Janvrin (1899) 174 Mass. 514, 55 N. E. 38I. But see Nebraska Tel. Co. v. State (1898) 55 Neb. 627, 76 N. W. I7I.

"Western Union Tel. Co. v. Myatt (1899, C. C. D. Kan.) 98 Fed. 335. And see Michigan Central R. R. v. Circuit Judge (1909) 156 Mich. 459, 470, 120 N. W. 1073, 1078; Detroit v. Railroad Commission (1913) I78 Mich. 250, 144 N. W. 689; Hall, ibid., 95, note; Prentis v. Atlantic Coast Line Co., supra; Louisville, etc., R. R. v. Garrett, supra. But cf. Saratoga Springs v. Saratoga Gas Co. (1908) 191 N. Y. 123, 148, 86 N. E. 693, 701; People v. Willcox (1909) I94 N. Y. 383,87 N. E. 517. The statutory power of a court to require obedience to an order of a commission by mandamus or injunction issued on application in behalf of the state would seem to be limited by this principle. See Ill. Pub. Util. Act, sec. 75; Fed. Trade Commission Act, secs. 5, 9. It is one thing to enjoin a man from further maintaining a particular house of ill-fame. It is another thing to order him to abstain from keeping any and all houses of ill-fame, or to obey the laws in general.

st See note I6, supra. 
A court has, however, a power to make rules, which arises from the fact that it may control its own procedure in a way that does not amount to a denial of the parties' rights to relief or conflict with statutes. So far as it may control its procedure, it may announce in advance the manner in which it will act, and its rules may create rights which it would be error for it to disregard, and which, when the making of rules is authorized by statute, create rights which rank with statutory rights. ${ }^{35}$

There is a class of cases in which judicial power is invoked to guide executive discretion, which merits special consideration. Administrative boards and officers often have to take action which depends upon their decision as to law and fact, and directly affects the rights of others. If they exceed their authority, a court may generally give redress. $^{36}$ But they may act within their authority, and yet incorrectly. A valid assessment may be too high, ${ }^{37}$ a license may be refused by mistake of law. A court is peculiarly fitted to decide questions of law and many questions of fact, and in the interest of good government it ought to be possible to obtain a court's decision, though there has been no violation of a legal right. It is competent for the legislature to give a court power, at the instance of a person aggrieved, to review administrative proceedings (other than rule making), determine what decisions of law and fact should have been made, and direct action in accordance with its findings. This is judicial action of a peculiar kind. No duty has been violated. The legislature has conferred on the person whose rights are affected, by the administrative action, a right to have the action changed and made correct, and has imposed on the court a duty of putting this right into effect. The court's action is analogous to issuing a certificate of incorporation, or of election, rather than to setting aside proceedings in excess of authority. The court merely determines what executive action was proper upon the evidence which the executive had before it. The decision is simply that given executive action shall or shall not take place. There is no adjudication on anything else. Thus where the issue of a patent for an invention is objected to on the ground that it infringes a previous patent, Congress may subject the patent commissioner's decision to review by a court, on the evidence before the commissioner, but the court's decision is only that the patent shall or shall not issue, and is not an adjudication that there is no infringement. If the patent is issued, the earlier patentee, though he was a party to the proceedings, may sue for infringement without prejudice. ${ }^{38}$

${ }^{25}$ See the discussion of administrative power to make rules, infra.

"Interstate Commerce Commission v. Louisville \& Nashville R. R. (1912) 227 U. S. 88, 33 Sup. Ct. 185.

${ }^{\pi}$ Spencer $v$. People (1873) 68 III. 510; see Porter v. Railroad, etc. (1875) 76 I1l. $56 \mathrm{r}, 595$.

s "It is evident that the appeal is not the exercise of ordinary jurisdic- 
So, too, an appeal may be granted from the verdict of a sheriff's jury as to the title to property attached, but the decision merely affects the action and "liability" of the sheriff, and does not settle the title. ${ }^{39}$ Other examples of court control over executive action that is valid but incorrect are furnished by appeals on the merits from taxingboards, ${ }^{40}$ assessments by drainage commissioners, ${ }^{41}$ rulings of election officers, ${ }^{42}$ and of registration officers, ${ }^{43}$ and in appeals on points of law from decisions of the Industrial Board in workmen's compensation cases. ${ }^{44}$ May an appeal also be granted from an administrative

tion . . . but is one in the statutory proceeding . . . in aid of the patent office. Its adjudication, though not binding upon any who choose by litigation in courts of general jurisdiction to question the validity of any patent thus awarded, is nevertheless conclusive upon the Patent Office itself." Butterworth v. Hoe (1884) II2 U. S. 50, 60, 5 Sup. Ct. 25, quoted in United States v. Duell (1899) 172 U. S. 576, 19 Sup. Ct. 286; Ewing v. Fowler Car Co. (Igr7) 244 U. S. I, II.

* Rowe v. Bowen (I862) 28 Ill. II6.

"Bureau County v. Chicago, etc., R. R. (1867) 44 IIl. 229.

"Owners v. People (I885) II3 IIl. 296.

"Sherman v. People (I904) 210 Ill. 552, 7I N. E. 6r8.

- See People v. McWeeney (rg13) 259 Ill. I6r, I02 N. E. 233.

"People ex rel. Muntn v. McGoorty (1915) 270 Ill. 610, 620, 110 N. E. 791. Some of the language in the Illinois cases seems inaccurate. In Aurora $v$. Schoeberlein (I907) 230 IIl. 496,82 N. E. 860 , a statute which allowed an appeal to the circuit court from any order of the board of fire commissioners was held wholly void. The decision seems right because the statute contemplated a review of questions of policy. Moreover the statute seems invalid as applied to the case before the court. It was an appeal by the fire marshal from an order removing him upon written charges. The legislature probably intended to make him removable for any cause which the board reasonably deemed sufficient, and the soundness of their reasonable discretion presented a matter of administrative policy which the legislature could not empower a court to control. But if it had been the board's duty to permit him to continue in office unless satisfied that specified cause for removal existed, then his right to office depended upon a decision of the board which involved nothing of policy, and called for discretion only in deciding questions of law and fact. The court's statement that there can be no appeal where there has been no decision by a legal tribunal runs counter to a common practice of vesting courts with power to direct the action of administrative officers in such cases. The officer's duty is to act in accordance with his own views of law and fact; but, in case on the review a court directs otherwise, then according to the direction of the court. It is immaterial that the statute calls this review an appeal. It is an original proceeding. As in mandamus, it is an application for an order telling an executive what to do. So in Maxwell $v$. People (I9or) I89 Ill. 546, 59 N. E. IIor, it was properly pointed out that a person who had not taken such a so-called appeal had not had his day in court and was not debarred of other remedy. But it differs from mandamus in not being founded on a breach of administrative duty. Nothing is involved but the question how the officer ought to act. The court also seems wrong in saying in Fair Ass. v. People (1884) III Ill. 559, that a decision made in reviewing executive action would be res adjudicata in other proceedings. An unsuccessful appeal from an assess- 
ruling which involves no decision except as to matters of law and fact, but which instead of affecting only a single case promulgates a rule of law for future transactions, for example an order fixing reasonable railroad rates ?45 The commission's work consists substantially in ascertaining, first, what the law means by "reasonable," a matter of law, though hardly yet ascertained; and, secondly, what rates possess those qualities designated as reasonable, which is in substance a question of fact as to the effect of given rates. Hence it would seem that a court might constitutionally be vested with power to review an order fixing reasonable rates, to set aside a ruling contrary to the weight of evidence, and to direct a ruling in accordance with it, ${ }^{46}$ though the language of some cases is to the contrary. ${ }^{47}$ It does not require the court to collect evidence or to promulgate the order, ${ }^{48}$ but only to ensure that executive action shall proceed upon a correct view of law and fact.

\section{ADMINISTRATIVE POWER}

The separation of powers does not require the legislature to settle all details of policy. Discretion belongs to the executive as well. It is enough if the legislature determines policies as far as is practicable, leaving to executive discretion the mode of carrying them out and

ment ought not finally to conclude as to the then value of the property. It should still be open to dispute the validity of the assessment on the ground the property was exempt, though exemption depended on value. See cases cited in notes 38 and 39, supra. Cases of substituted original jurisdiction, where the so-called appeal sets aside the previous action and a trial de novo is had on the merits are not in point. They are exercises of ordinary judicial power.

w The Interstate Commerce Act does not authorize such an appeal, and consequently a ruling can be set aside only when the commission has exceeded its constitutional or statutory authority. Interstate Commerce Commission v. Illinois Cent. R. R. (1910) 215 U. S. 452, 30 Sup. Ct. I55. But the statute is interpreted as intended to confer authority to act only upon evidence, so that a ruling is invalid where contrary to the indisputable character of the evidence. See Interstate Commerce Commission v. Louisville, etc., $R$. $R$., supra.

* Saratoga Springs v. Saratoga Gas Co., supra; People v. Willcox, supra; Minneapolis, etc., R. R. v. Railroad Commission, supra; and see Public Utilities Commission v. Chicago, etc., $R$. $R$., supra; Public Utilities Commission v. Atchison, etc., R. R. (Ig17) 278 Ill. 58, 75, Ir5 N. E. 904; Sears, Roebuck \& Co. v. Federal Trade Commission (I919, C. C. A. 7th) 258 Fed. 307 (1919) 29 Y ALE LAW Journal, 125, 126; Federal Trade Commission v. Gratz (1919, C. C. A. 2d) 258 Fed. 314; Troutman v. Smith (1899) 105 Ky. 23I, 48 S. W. 1084. Cf. Chicago, etc., R. R. v. Public Utilities Commission (I9I5) 268 I1l. 49, 108 N. E. 720; Public Utilities Commission v. Terminal, etc., $R$. R. (19I7) 28I Ill. I8I, II8 N. E. 7I.

"Reagan v. Farmers', etc., Co. (1894) x54 U. S. 362, 397. 399, I4 Sup. Ct. I047; Steenerson v. Great Northern R. R. (1897) 69 Minn. 353, 72 N. W. 713. And see Detroit R. R. v. Michigan R. R. Commission (1914) 235 U. S. 402, 35 Sup. Ct. I26.

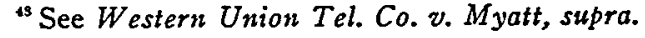


the occasions on which action is required. ${ }^{48}$ What the executive may accomplish by action it may accomplish without exceeding the limits of executive power by order. For illustration, as the legislature may empower the executive to prevent accidents and crowding by taking charge of traffic at street intersections, leaving to executive discretion the streets at which control of traffic is required and the mode of controlling it, so it may empower the executive to control it by making regulations and enforcing them. This vests the executive with power to make laws. ${ }^{50}$ But making laws of this character is not a non-executive function, a usurpation of legislative power any more than control to the same extent by the discretionary use of force would be. So far as concerns the principle of the separation of powers, it is all one whether the police stop a horse at a street crossing by seizing its head, or by telling its driver to stop, or by issuing a rule requiring everybody to stop.

Thus the legislature may empower customs officers to exclude unwholesome teas by fixing standards of wholesomeness as well as by discretionary action in each case, ${ }^{51}$ inspectors to fix the character of fire escapes by regulation as well as by separate approvals, ${ }^{52}$ and a prison board to govern its discipline of convicts by rules. ${ }^{53}$ Upon this principle rest the rule making powers of civil service boards; $;$; of boards of health ${ }^{55}$ of the department of the interior concerning the use of the public domain $;^{56}$ and of the interstate commerce commis-

"Hawthorn v. People (1883) I09 Ill. 302 (clerk of court may determine sufficiency of sureties); Spiegler $v$. Chicago (1905) 216 I1l. 1I4, 74 N. E. 718 (drip pans must be such as commissioner of public works approves); Block v. Chicago (I909) 239 Ill. 25I, 87 N. E. Iorr (picture films must be such as chief of police deems moral); People v. Apfelbaum, supra (physician's license may be revoked for dishonorable conduct); Klafter v. Board (I9r3), 259 Ill. 15, 102 N. E. 193 (architect's license may be revoked if he is thought grossly incompetent) ; Alton \& Southern R. R. v. Vandalia R. R. (1915) 268 Ill. 68, 108 N. E. 800 (railroad crossing must be approved by commission). "The legislature . . - may designate others to do those things which it can appropriately yet cannot understandingly or advantageously do itself") ; People v. Stokes (1917) 28I Ill. 159, II8 N. E. 87 (license may be revoked if bond deemed insecure); Public Clearing House v. Coyne (1904) r94 U. S. 497, 24 Sup. Ct. 789 (postmaster may exclude article he deems fraudulent).

${ }^{5}$ U. S. Rev. St. 1878 , sec. 4405 gives steamboat inspectors power to establish regulations necessary to carry out the provisions of the act. The regulations cover more than a hundred pages.

${ }^{" B}$ Buttfield v. Stranahan (I904) I92 U. S. 470, 24 Sup. Ct. 349.

${ }^{32}$ See Arms v. Ayer (rgor) 192 Ill. 601, 6r N. E. 851.

s George v. People (1897) 167 Ill. 447.47 N. E. 741.

"People v. Kipley (1898) 171 Ill. 44, 49 N. E. 229; Fisk v. McGann (1903) 205 Ill. 179, 68 N. E. 76r ; People v. McCullough (1912) 254 Ill. 9, 98 N. E. 156; People v. Rischo (1914) 262 Ill. 596, 105 N. E. 8.

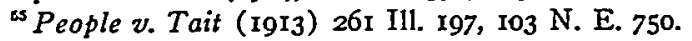

- United States v. Grimaud (IgII) 220 U. S. 506, 31 Sup. Ct. 480. 
sion as to the form of railroad accounts. ${ }^{57}$ The farther administrative control by use of force extends, the farther goes the power of making rules. The power to command the army in management, discipline and drill may be exercised by army regulations and by courts martial administering a military law.

Conversely an attempt to empower a customs officer to collect such duties as he thinks proper, a board of pharmacy to determine whether or not to issue licenses to sell patent medicines, ${ }^{58}$ or a fire marshal to require safety appliances in cases of danger, or to dispense with them, as he thinks best, ${ }^{50}$ is invalid as vesting in an executive a kind of discretion which under the constitution belongs only to the legislature, though it does not involve his imposing any regulations at all. ${ }^{60}$

It is plain that administrative officers may be empowered to take specific action in executing the law on condition that the specific facts exist on which the law depends, and to take measures necessary to decide whether or not the facts do exist and whether or not the law does authorize action, in order to act accordingly, and that this involves no exercise of power judicial in such sense as to be non-administrative. $^{\text {a1 }}$ However it is sometimes said that in such cases administrative officers act judicially, ${ }^{62}$ and the statement, though tending to confusion, is correct if it merely means that their mental processes resemble those of courts, or that due process may require a hearing, or that their resulting action may, like a judgment, be final, in that it may (as in awarding a pension or a civil service rating) confer a right which cannot be rescinded except for a distinct cause.

More than this, the legislature may authorize an officer to act, not merely when specified facts really exist, but when, after such investigation as due process of law may require, he deems them to exist. ${ }^{63}$

"Interstate Commerce Commission v. Goodrich Co. (IgI2) 224 U. S. I94, 32 Sup. Ct. 436. The legislature may empower a commission to order the attendance of witnesses and make it a misdemeanor to disobey the order. People v. Kipley, supra; Interstate Commerce Commission v. Brimson, supra.

${ }^{s s}$ Noel v. People (Igoo) I87 Ill. 587, 58 N. E. 616.

"Sheldon v. Hoyne (1913) 26I Ill. 222, 103 N. E. I02I.

${ }^{\infty}$ The pardoning power, like the veto, is a legislative power of negative nature, vested by the constitution in the chief executive, as a check upon injustice; 'historically it is a relic of executive supremacy.

${ }^{6}$ Cf. People v. Brady (1915) 271 Ill. 100, I10 N. E. 864. People v. Stokes (1917) 28 I III. I59, II 8 N. E. 87 (pawnbroker's license to be revoked if he has violated statute. Craig, J., said, at 175 , "No power is conferred upon the department to adjudicate upon the rights and interests of parties or to construe and apply the law. . . . While the determination ... requires the exercise of judgment and discretion, and to that extent is of a judicial nature, it is not judicial power").

"See Devine v. Brunswick-Balke Co., supra.

* People v. Simon (1898) 176 I11. 165, 52 N. E. 910 (registrar under Torrens Act need record only transfers he deems valid); People v. Apfelbaum, supra (Dunn, J., said of the revocation of a physician's license for dishonorable 
Thus in the much discussed $J u$ Toy case ${ }^{64}$ it was held that Congress, having under its legislative power denied to alien Chinese a privilege to enter the United States, could provide for the enforcement of the law, by empowering collectors of ports to exclude persons of the Chinese race, provided, after inquiry, they deemed them (though mistakenly) to be aliens. It is the same principle which authorizes

conduct, "It is similar in its nature to the acts of assessors in assessing property for taxation; of boards of review in reviewing such valuations; of clerks of courts and sheriffs in approving bonds taken by them; of commissioners of highways in laying out and opening roads; of city councils in granting or revoking licenses to keep dram shops, or of superintendents of schools in granting or revoking teachers' certificates"); People v. Brady (I9I5) 268 Ill. 192, 108 N. E. 1009 (auditor authorized to withhold permit to organize bank he believes to be for unauthorized purpose); People v. Sweitzer (I9I4) 266 IIl. 89 , I07 N. E. I32 (legislature may provide that person shall be entitled to office whom canvassing board deems to have received most votes); Donahue v. County of Will (I88I) roo Ill. 94 (right to county office to cease, if board finds holder to be a defaulter). See also cases in note 49, supra. The distinction between deciding upon a legal right for the purpose of taking such administrative action as the law directs or authorizes in case the right exists, and deciding upon a legal right for the purpose of adjudicating and determining it, may be illustrated by comparing the preceding cases with those that follow: Cleveland, etc., R. R. v. People (1904) 212 Ill. 638, 72 N. E. 725 (an assessor cannot be empowered to impose a penalty for misconduct); Hall v. Marks, supra (clerk of court cannot enter judgment on default); Poppen $v$. Holmes (I867) 44 Ill. 360 (poundkeeper cannot be empowered to sell estray for penalty he deems due); Bullock v. Geomble (I867) 45 Ill. 218 (legislature cannot confer on "three disinterested men" power to assess damages caused by cattle running at large). See also People ex rel. Kern v. Chase (1897) I65 Ill. 527, 46 N. E. 454, which holds that the legislature cannot empower a registrar under the Torrens Act to make title to land good by registering it. It may be doubted, however, whether the facts brought this case within the principle, for the act of the registrar did not directly validate title, but only started the running of a short statute of limitations. It seems analogous to Devine $v$. Brunswick-Balke Co., supra, which holds that the legislature may make the verdict of a coroner's jury prima facie evidence of the cause of death.

The Interstate Commerce Act forbids excessive charges and unfair discriminations. Yet however excessive a charge has been or however unfair a discrimination, if it was in accordance with the carriers' duly published regulations, no court may award damages for the violation of the act, unless the Interstate Commerce Commission has first ruled that such a charge or discrimination would violate the act. Loomis v. Lehigh Valley $R$. R. (I916) 240 U. S. 43; Northern Pacific R. R. v. Solum (1918) 247 U. S. 477. The commission's determination as to the character of the alleged charge or discrimination is conclusive, both as to the carrier and as to the shipper. Phillips Co. v. Grand Trunk, etc., R. R. (1915) 236 U. S. 662, 35 Sup. Ct. 444; Pennsylvania R. R. v. Stineman Coal Co. (1915) 242 U. S. 298, 37 Sup. Ct. II8. This determination as to past rights looks at first sight like an exercise of judicial power. In truth, it is precisely parallel to the establishment of rates and practises for the future. It is an administrative determination of fact as to the character of the rate or practise, and the promulgation of the rule of law concerning it which the legislature has provided for. But instead of 
policemen to prevent boys skating on ice, which the policemen, though mistakenly, think too thin. There is no exercise of judicial power in any degree. There is merely a decision by an executive that a case has arisen in which it is his duty to act. If in acting, he exceeds his authority, a person aggrieved has his remedy, by injunction, mandamus, habeas corpus, or suit for damages, as the case may be. If there has been no excess of authority, there is nothing for a court to redress. Whether there is excess of authority may depend on whether the legislature has seen fit to condition authority on the truth as to the facts, or on the officer's opinion as to them. When a policeman is authorized to prevent skating if he thinks the ice too thin, and acts mistakenly, the only remedy the boys have is to wait for another occasion. They may apply for permission five minutes later, if they wish, and the case is a new one. In the $J u$ Toy case, if the collector's authority had only been to exclude those who were aliens in fact, Ju Toy, if really a citizen, could have obtained from the court a release from detention. If he were not of Chinese race, but looked like a Chinaman, he could have had his release, for the collector's authority happened only to be to detain those who were really Chinese and who were or whom he thought to be aliens. As it was, the collector had a right to exclude Ju Toy; but it would be a great mistake to suppose that the collector's decision deprived him of anything except ability to enter the country on that occasion. He could have come again to the United States and applied for admission before the same or any other collector, and he would have had a right to a new ruling. If, while detained, he had sued the collector for false imprisonment in a United States court, alleging that he, Ju Toy, was a citizen of one state, and the collector a citizen of another, the court might have decided that he was a citizen and that it had jurisdiction, at the same time it decided that the imprisonment was not illegal and gave judgment against him on the merits.

being promulgated for the future, the rule is promulgated, in a sense retroactively, to govern all past transactions. The explanation is found in the fact that the Interstate Commerce Act while it expressiy prohibits excessive rates and unfair discriminations, nevertheless, in order to secure uniformity in the treatment of shippers, also provides, in effect, that regulations duly published shall be obligatory unless and until the commission rules that they are counter to the act. A carrier thus establishes a rule at the risk of being bound to follow it while it is in force, and of becoming liable in damages, if the commission after the event, displaces it and substitutes a different standard, as being the course of conduct which the carrier was bound to follow. The new standard, accordingly, furnishes the measure of the rights of all shippers, whether they took part in the proceedings by which it was established or not. Phillips Co. v. Grand Trunk, etc., R. R., supra; Pennsylvania R. R. v. Puritan Coal Co. (1915) 237 U. S. I2I, 13I, 35 Sup. Ct. 484; Loomis v. Lehigh Valley $R$. R., supra; Pennsylvania $R$. $R$. v. Stineman Coal Co., supra.

${ }^{64}$ (Ig05) I98 U. S. 253, 25 Sup. Ct. 644. 
In cases like this, discussions as to the degree in which administrative action may involve an exercise of judicial power are beside the point. Such administrative action is not judicial in any degree. But the fact that authority may be made to depend on a variety of facts, and either on facts or on belief as to facts, illustrates the elasticity in governmental method which is possible within the limits imposed by the separation of powers. Separation prevents the executive from adjudging controverted individual rights, or from making strictly legislative determinations of policy, but it leaves the legislature abundant opportunity by enlarging executive discretion and authority to contract the area within which courts are capable of giving protection in order to extend the area in which the executive may act with freedom. It makes some abuses impossible and diminishes the temptation to others and thus, as Professor Burgess has said, it "has a tendency to retard the development of government in its almost inevitable tendency to absolutism." "65 For beside the positive limitations that separation imposes, it enables the legislature, being prevented from itself exercising either the executive or the judicial power, to hold the balance impartially between the positive and negative functions of government, between the promotion of social interests and the judicial protection of rights. But to secure impartiality is not in itself to secure justice or wisdom. A well balanced diet is not a warranty of health. Powers arbitrary or discordant may sometimes be bestowed on others as well as grasped for one's self, and it is possible for a legislature so to extend the boundaries of executive authority and discretion, that the executive, within its realm, may act pretty largely according to its own views of policy, law and fact. It is where there are real abuses to correct that the practice of arbitrary power begins, and the danger "is always greater where the purposes for which it is exercised are good" because there it is less easy to see the danger. ${ }^{68}$ "Good men in good times should beware of setting bad precedents for bad men in bad times." life who, alarmed at the development of an industrial oligarchy, seek, apparently from impulse rather than from reason, like chickens frightened by a hawk, to run under the wings of a mother government. In the early middle ages kings in France administered justice under

\footnotetext{
s Burgess, The Reconciliation of Government with Liberty (1893) 305.

* Pierce, Federal Usurpation (1908) ch. 10. See his account of the practice of stopping all mail addressed to persons suspected of fraud, and of the workings of administrative classification of mail matter, and determination as to objectionable character.

or "Those who meditate a recourse to arbitrary power for a good purpose should pause to consider the consequences, for it is a vice which brings in its train all the vices, and especially the detestable vices of official extortion and blackmail." Gaynor, J., in People ex rel. Lodes v. Department of Health (1907) 117 App. Div. 856, 865, 103 N. Y. Supp. 275.
} 
an oak, and to-day some commissions are doing much the same thing, for we have empowered them to deal with all sides of a subject, feeling surer that, so, their powers will be adequate. It is worth while to consider the extent of administrative power under some of our statutes, and to inquire whether, as in the government as a whole, so within certain boards and commissions, it would not be feasible to introduce some measure of balance or division of function.

The Illinois Workmen's Compensation law ${ }^{68}$ establishes an administrative $^{69}$ industrial commission and imposes on it some purely administrative functions, such as filing notices from employers who elect to come under the act, notifying those whose employers refuse to come or to continue under it, preparing and furnishing forms, receiving notices of the circumstances of accidents, and approving the sufficiency of insurance. The commission must approve any waiver of a right conferred by the act or the waiver will not be binding, and it may, on application, decide whether the compensation shall be payable by installments or in a lump sum. These are virtually powers to give or withhold licenses upon principles expressed or implied in the statute and seem to be administrative in the constitutional sense. But the act goes farther. When a claim is made for compensation, all questions of fact are finally determined by the commission or by an arbitrator appointed by it. An employer may deny that any injury was received, or that it was of the character or happened under the circumstances claimed. If there is any conflict in the evidence the commission's decision for or against him is final, and the circuit court must give judgment in accordance with it. In its earlier form, the act was elective, and the commissioner's power was upheld on the ground that the legislature might enact that decisions should impose liability on those who by electing, consented in advance to becoming liable. ${ }^{70}$ When it had been established that it was consistent with due process of law to compel an employer to make compensation for accidents not attributable to his fault, ${ }^{71}$ the Illinois law was made compulsory as to hazardous employments. But it is believed that it has not, at this writing, been decided that a compulsory compensation statute may give an administrative body power to determine the facts which govern liability between employer and employed. ${ }^{72}$ If a desire to avoid a

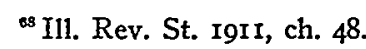

${ }^{\circ}$ Ill. Rev. St. 1917, ch. $241 / 2$, pars. 5, 43, 44; ibid., ch. 48, par. I1o.

${ }^{70}$ Deibeikis v. Link-Belt Co. (I9I4) 26I Ill. 454, IO4 N. E. 2II; Johnson v. Choate (I918) 284 Ill. 2I4, 2I8, II9 N. E. 972.

"New York Cent. R. R. v. White (1917) 243 U. S. 188, 37 Sup. Ct. 247, 215 N. Y. 514 .

"New York Cent. v. White, supra, and Western Indemnity Co. v. Pillsbury (1915) r7o Cal. 686, I5I Pac. 398, are not in point because the state constitutions empowered the legislature to vest the board with authority to determine controversies. In the former case, Pitney, J., said: "Provision is made for the establishment of a Workmen's Compensation Commission with administrative 
trial by jury is the motive for conferring the power on a commission, it would seem a less momentous change to abolish the right to trial by jury in such cases, rather than to take the cases, not only from a jury but from the court as well, and to transfer the decision from elected judges to appointed administrators.

The Illinois Public Utilities Commission is charged with the enforcement of the utilities act and is required to inquire into the conduct of the business of all public utilities, and to regulate their manner of keeping accounts. It may investigate accidents and claims for damage, ascertain values and require additions to plant or service, or modification of rates. Without its permission no utility may begin business or do new business, or issue securities, or make a mortgage, or sell or lease necessary property, or contract for joint operation, or invest in shares or bonds of another utility. Permission is to be granted or withheld as the commission is or is not satisfied, in some

and judicial functions." Cunningham v. Northwestern Improvement Co. (IgII) 44 Mont. I80, IIg Pac. 554, is not in point because payment was from a state insurance fund, and it was held that an administrative officer might pass on the validity of claims to its disbursement for the purpose of paying it out or withholding it. "Any controversy which may arise concerning the mere administrative duty of collecting and distributing the fund may be decided in such summary fashion as the state may prescribe."

The Michigan and Wisconsin statutes were only compulsory as to cities. In Wood v. Detroit (1915) I88 Mich. 547, I55 N. W. 592, an award was enforced against the city, but the report does not indicate that any point was taken, as to its involving an exercise of judicial power by the board. The decision goes on the ground that the city's liability to its workmen is a public matter, under legislative control. In Borgnis v. Falk (I911) 147 Wis. 327, I33 N. W. 209, Winslow, C. J., pointed out that the act was elective, and that the board's jurisdiction rested on the consent of the parties. It is true that he said the board acted only quasi-judicially and that its decision was conclusive, but his language has no proper application to the point under consideration here. A legislature certainly could not establish a commission for the enforcement of contracts, and charge it with the duty of ascertaining on complaint whether a contract had been broken and of awarding damages for the breach. Nor are those cases analogous which hold that the government may empower the executive to determine and enforce rights which the state itself has, as a part of the process of administration, as in assessing and collecting taxes. Rhinehart v. Schuyler (1845) 7 Ill. 472, 521; Spencer \& Gardner v. People (1873) 68 Ill. 510; Porter v. Rockford, etc., R. R. (1875) 76 Ill. 561, 595; Bartlett v. Kane (1853, U. S.) I6 How. 263, 14 L. ed. 931; Springer v. United States (1880) I02 U. S. 586; Hilton v. Merritt (1884) I10 U. S. 97, 3 Sup. Ct. 548; or in taking for public use. See Bauman v. Ross (1897) I67 U. S. 548, 593, I7 Sup. Ct. 966 ; or in issuing a distress warrant for the amount found due from a defaulting public officer. Murray's Lessee v. Hoboken Co. (1855, U. S.) I8 How. 272. Under the compensation act, the employer's money is not taken by the government nor for its use. The employer is required to pay it to the employee for the employee's use. The commission is a tribunal to determine rights between contending parties. See also State v. Johnson (1900) 6I Kan. 803 , 60 Pac. I068 (railroad commission cannot be empowered to determine private disputes) and cases in note 63 , supra. 
instances, that it should reasonably be given and will convenience the public, in others, that public necessity requires it, in others, apparently, that it is consistent with the purposes of the act. Furthermore, the commission may, on complaint or on its own initiative, after hearing, prescribe reasonable rates, or, in cases of unreasonable discrimination, rebate, overcharge, and other violations of the act, make such order as may be appropriate, subject to appeal to a court; and on appeal, the commission's finding of fact shall be conclusive unless clearly against the manifest weight of evidence. In cases of alleged excessive or discriminatory charges, it may, after hearing, make findings of fact which shall be prima facie evidence in court. These provisions, though constitutional, manifest a purpose of making the commission, so far as constitutional limitations will permit, at once an administrator of utilities, a decider of policy, and a judge of facts.

The Act of Congress of I9I4 creating a Federal Trade Commis$\operatorname{sion}^{73}$ is another illustration of prevailing tendencies. It is aimed at unfair competition in interstate commerce. Its provisions are not entirely clear, but to bring out its character, let us suppose that instead of dealing with commercial unfairness, it dealt with conjugal cruelty. Then, apparently, it would run as follows: Husbands shall not treat their wives cruelly. If the commission has reason to think that any husband is treating his wife cruelly, it may notify him of the fact, specifying in what the supposed cruelty is supposed to consist, as for example that he smokes in the house though the smell of his tobacco annoys his wife. It shall also select some place in the United States, and notify him that if he appears there at a fixed time he shall have the privilege of showing cause why an order should not issue commanding him to cease smoking in the house. Moreover the commission may by subpoena require him, his wife, his servants or his neighbors to attend at any place in the United States and to submit to examination on the subject. If the commission, on the evidence, considers that he has indulged in a practice of smoking to his wife's annoyance and that this constitutes cruelty, it shall order him to desist. But it is necessary to be careful, and therefore this order shall not be enforced until the commission, or any person who feels interested, brings it before a court and secures the court's opinion that there was some evidence of such smoking in the house to his wife's annoyance, as to constitute cruelty. If the husband is still contumacious, a court may then order him to obey the commission, and, if thereafter he smokes in the house, he may be punished, not for cruelty to his wife, but for disobedience to the order of the court directing him to perform his duty of obeying the order of the commission.

Thus the interpretation of the law has been in effect devolved upon the commission, and the culprit warned in advance to desist, and a trial by jury obviated by making him summarily punishable for

${ }^{73}$ Act of Sept. 26, 1914, ch. 311 ; 38 U. S. Stat. L. 717. 
contempt. Whatever it might think of marital cruelty, Congress, when it comes to the matter of commercial unfairness, warned by experience under the Sherman Act, realizes that it is unable to define what it wants to forbid and deems this method better than the ordinary one of specifying and prohibiting an offense and prosecuting those who commit it. St.-Girons quotes a saying of Thiers that experience is the only real law maker. Unfortunately experience can never speak her last word.

The foregoing statutes illustrate a prevalent disposition to regulate a given subject-matter by fixing only the fundamentals of policy by statute and by concentrating a close governmental control over all of its aspects in a single body of experts, clothed with as wide a discretion, and with as broad a power to determine law and fact as constitutional limitations will permit, so that they may come as near as possible to making, judging and enforcing their own decrees. For this purpose, their authority is conditioned, not on facts, but on their belief as to facts, and court review, when granted at all, is restricted to cases of manifest error. This is not in itself a violation of the constitutional separation of powers, ${ }^{74}$ nor a denial of the desirability of separating them. But it does indicate a belief that there is a need for subjecting, within constitutional limits, many matters to administrative control, even at the risk of dangers which a separation of functions would minimize. This suggests that it may be possible to obtain the advantages both of distribution of function and of expert and concentrated control, by a division of function within the commission. For though a desire for prompt concerted action, the difficulty of defining authority, and a wish to give free scope to expert knowledge may be urgent reasons for conferring unhampered power, yet it exposes those subject to it to a risk of injustice, and even of oppression, to uncertainty, and to the repressive influence of the fear of arousing disfavor. Strafford, Viceroy in Ireland of Charles I, wrote, "The king is as absolute here as any prince in the world can be"; but he excused the weaker administration of his predecessor by saying that he was unable to judge between party and party "which certainly did lessen his power extremely." Where regulation is directed against specific persons as in rate-making, cases of unfair competition, and sometimes in action by boards of health, it partakes of the character of a judgment as well as of a law. The fundamental securities deemed necessary in court proceedings are necessary here. The propriety of a preliminary hearing is obvious, and a right to it has generally been secured, except in cases of supposed emergency, and sometimes in cases of difficulty in reaching the parties. It might

\footnotetext{
"But it may be questioned if in some instances the line has not been passed. See note 72. Quaere whether secs. 76 and 77 of the Public Utilities Act are intended to, or can validly, apply to orders made under sec. 72 , and whether sec. 72 can authorize reports on damage done except for purposes of later action.
} 
well be guarded more carefully than it has been. ${ }^{\text {is }}$ If the action of the commission is so similar to the action of a court as to make a hearing necessary, the similarity also suggests the desirability of a like division of function in the tribunal. Neither a court nor a commission shoukd be a prosecutor. Utilities commissions and other commissions charged with correcting abuses in particular fields are like standing committees of the legislature. A person aggrieved by discrimination or overcharge may be expected to call the attention of the board to his case, but hardly to take upon himself the entire burden of prosecuting it as if against an adversary. $\mathrm{He}$ is rather in the position of a victim of crime and entitled to governmental prosecution in his behalf. The records and facilities of the commission should be at his disposal. And the board should be alert of itself to discover and correct abuses. Boards recognize these facts and inevitably and properly become in some degree partisans of those who make complaints. But the law which subjects them to the bias of prosecutors sets them up as judges. It requires them to be fair without permitting them to be impartial. Utilities and investors realize the situation, and stock exchange prices elucidate Montesquieu's saying that there is no liberty where there is apprehension.

Government by commission substantially subjects to court-martial those with whom it deals. But whereas a court-martial might be supposed at least to apply fairly definite rules of established law, a commission generally exists for the very reason that the principles it is to apply are so vague that the legislature is unable to lay down a rule sufficiently definite for a court to act on. Because it is deemed impracticable to disentangle law from fact, to legislate by general rule specifying ascertainable facts, the legislature delegates to a commission a discretion which a court is incapable of receiving, and empowers it to make and to apply its own rules in a series of decrees for special cases.

Why not separate members of the commission who are to prepare and present the cases (whether ex parte or on complaint) or to supervise that work, from the members who are to decide the cases and issue the orders? This would be, in a limited way, analogous to the French system of special administrative courts which deal with administrative matters as members of the administrative, not of the judicial department. It would lessen the converse and real danger that a board may insensibly come under the influence of the interests it was intended to supervise. From such influences insurance commissioners, bank examiners and tax assessors have not always been immune.

\footnotetext{
${ }^{75}$ See Commonwealth v. Sisson (I905) I89 Mass. 247, 75 N. E. 619; Lawton v. Steele (1894) I52 U. S. 133, I4 Sup. Ct. 499; Oceanic Steam Nav. Co. v. Stranahan (1909) 214 U. S. 320, 29 Sup. Ct. 671; Murray v. Hoboken Land Co. (1855, U. S.) I8 How. 272.
} 


\section{CONCLUSION}

In conclusion, it is submitted that though in the increasing complexity of governmental activity it has become necessary to vest administrative officers with an authority less closely restricted, and thus to narrow the field in which courts can give relief against executive mistake, as well as the field in which the doctrine of the separation of powers has application, it is nevertheless quite untrue to say that the doctrine is unreal or has broken down. On the contrary, the cases show it to be active, effective and capable of consistent application. It may not be possible to condense a complete statement of it into an epigram, but it will not do to reject every epigram, as if it had no substantial truth. Martial law is only the fusion of powers in a single chief. It may or may not be regrettable that government nowadays takes control of matters about which the legislature cannot make laws sufficiently precise to be applicable without aid from the rule-making powers of a commission. Still there is an immense difference between this and turning things over carte blanche to an executive. The limits of executive discretion under the constitutional separation of powers remain the limits of rule-making power, nor within these limits is a legislature so likely to confer an unnecessary discretion on an independent and coördinate authority as on a committee of its own membership. Further, executive decision as to facts or law cannot determine anything but the executive action for the occasion. Adjudication is preserved for the courts. By compelling a distribution of authority over every subject-matter of government, the separation of powers insures to the holders of authority a position of relative impartiality which lessens the likelihood and the apprehension of unfairness, while it has been proved to possess elasticity enough to permit the conferring of fairly sweeping and summary powers where needed. It also serves to make plain the character of given governmental action. It helps everybody to understand how the government works, what it is doing and why. It makes it clear whether the government intends to create a new right, or to enforce an existing one, and whether an existing right is being enforced as between private persons, or by way of administering public affairs. ${ }^{76}$ It also concentrates on each department responsibility for the proper performance of its peculiar function and since the work of each department calls for special aptitude and experience, it brings about a desirable division of labor. ${ }^{77}$

\footnotetext{
"See Laski, ibid., 73.

"See Hamilton, Federalist, no. 8r. It is, however, true that these latter advantages might sometimes be secured by a division of powers according to the subject-matter dealt with, instead of according to the mode of dealing with it.
} 